\title{
Unusually high incidence of tuberculosis among boys with haemophilia during an outbreak of the disease in hospital
}

\author{
AC BEDDALL, FGH HILL, RH GEORGE, MD WILLIAMS, K AL-RUBEI \\ From the Departments of Haematology and Microbiology, The Children's Hospital, Birmingham
}

SUMMARY Of 30 children with bleeding disorders exposed to an index tuberculosis case, six developed primary pulmonary tuberculosis and two others became positive skin reactors. There was a significant correlation between the amount of replacement treatment received and the development of evidence of tuberculous infection. Only two of those who developed evidence of tuberculosis had antibodies to the human $T$ cell lymphotropic virus. These two boys showed much later Mantoux positive conversion than the six others.

We commented previously on an unusual susceptibility to tuberculosis among children with bleeding disorders exposed to tuberculosis on a hospital ward. ${ }^{1}$ Of 16 inpatient haemophiliacs exposed, six developed pulmonary tuberculosis. This incidence (38\%) was similar to that among immunocompromised children receiving cytotoxic chemotherapy for leukaemia and solid tumours (10 of 21 exposed $(48 \%)$ ) and considerably greater than that among children with other disorders (three of 75 exposed $(4 \%)$ ). Shortly afterwards reports described opportunistic infections occurring in patients with haemophilia $\mathbf{A},{ }^{2}$ some of whom fulfilled criteria for the acquired immune deficiency syndrome (AIDS). ${ }^{3}$ Immunological abnormalities suggesting defective cell mediated immunity are now well documented in asymptomatic haemophiliacs, ${ }^{4}$ including children, ${ }^{5}$ and may be related to type and quantity of coagulation factor replacement. ${ }^{6-8}$ Abnormal cell mediated immunity may have been a predisposing factor in the development of tuberculosis in our children with bleeding disorders. We therefore compared those children who contracted tuberculosis with those exposed (at risk) who did not. Immunological and haematological variables were studied, type and quantity of treatment defined, and other possible risk factors (including antibodies to human $\mathrm{T}$ cell lymphotropic virus (HTLV-III)) evaluated.

\section{Patients and methods}

During November 1981 a patient was investigated

Accepted for publication 6 June 1985 on a ward at our hospital and three weeks later was found to have tuberculosis of the spine. Her mother, who had visited her regularly during this period, was subsequently shown to have open pulmonary tuberculosis. The ward is used for patients with haematological and oncological disorders, in addition to children with other conditions, and also accommodates the outpatient haemophilia unit. After the discovery of the index case all the children had Mantoux tests and chest radiography. Thirty children with bleeding disorders had been placed at risk. Of these, 16 had been inpatients and 14 had attended the haemophilia unit as outpatients. Of the inpatients, 13 had haemophilia $\mathrm{A}$, two haemophilia $B$, and one von Willebrand's disease. The outpatients comprised six patients with haemophilia, two with haemophilia $B$, one with factor $X$ deficiency, and five with von Willebrand's disease. At the time of study none of these patients was taking drugs.

The patients with haemophilia $A$ had all received lyophilised factor VIII concentrates (both Armour intermediate purity factorate and NHS factor VIII concentrates). The patient with factor $\mathrm{X}$ deficiency and those with haemophilia B had received NHS prothrombin complex concentrates, while those with von Willebrand's disease had been given only cryoprecipitate. The amount of treatment was calculated as the mean yearly use over the preceding four years, and a separate analysis was made of the units consumed over the one year before exposure to tuberculosis.

Full blood counts were performed (Coulter S) and differential white cell counts performed on Wright 
Results expressed as means (SEM)

\begin{tabular}{|c|c|c|c|c|c|c|c|c|}
\hline Group & $\begin{array}{l}\text { Age } \\
\text { (years) }\end{array}$ & $\begin{array}{l}\text { Yearly treatment } \\
\text { (factor units) }\end{array}$ & $\begin{array}{l}\text { Treatment one } \\
\text { year before } \\
\text { exposure (factor } \\
\text { units) }\end{array}$ & $\begin{array}{l}\text { Total white } \\
\text { cell count } \\
\left(\times 10^{*} / l\right)\end{array}$ & $\begin{array}{l}\text { Lymphocytes } \\
\left(\times I 0^{*} / l\right)\end{array}$ & $\begin{array}{l}\text { Platelets } \\
\left(\times 10^{\prime} / l\right)\end{array}$ & $\begin{array}{l}\text { T4:T8 } \\
\text { ratio* }\end{array}$ & $\begin{array}{l}\text { No with } \\
\text { hypergamm } \\
\text { globulinaer }\end{array}$ \\
\hline
\end{tabular}

\begin{tabular}{|c|c|c|c|c|c|c|c|}
\hline $\left.\begin{array}{l}\text { Patients with pulmonary } \\
\text { tuberculosis }(n=6) \\
\text { reactors }(n=2)\end{array}\right\}$ & $11 \cdot 5(1 \cdot 12) 27451(6911)$ & $51443(17555)$ & $4.84(0.55)$ & $2 \cdot 15(0 \cdot 39)$ & $212(20)$ & $1.49(0.3)$ & 3 \\
\hline $\begin{array}{l}\text { Inpatients without } \\
\text { tuberculosis }(n=9)\end{array}$ & $10 \cdot 9(1.26) 14700(3786)$ & $20851(5974)$ & $5 \cdot 21(0.54)$ & $2.65(0.39)$ & $215(40)$ & $1 \cdot 21(0 \cdot 24)$ & 5 \\
\hline $\begin{array}{l}\text { Outpatients without } \\
\text { tuberculosis }(n=13)\end{array}$ & $10 \cdot 1(1.67) 12565(3698)$ & $12608(12127)$ & $5.70(0.52)$ & $2.58(0.33)$ & $197(28)$ & $1 \cdot 20(0 \cdot 17)$ & 1 \\
\hline
\end{tabular}

*Mean T4:T8 ratio in 59 normal children aged 11 months to 18 years is 2.06 (SEM 0.11).

stained peripheral blood films. Platelets were counted using a TOA platelet counter (PL100). Lymphocyte subpopulations were measured on mononuclear cells separated on a Ficoll-Hypaque gradient and defined by indirect immunofluorescence using the monoclonal antibodies T4 (includes helper) and T8 (includes suppressor) supplied by Coulter Electronics. Immunoglobulins were measured by an immunoturbidimetric method and compared with reference values matched for age. Serum samples stored at $-20^{\circ} \mathrm{C}$ were subsequently tested by Dr P Mortimer (Public Health Laboratory Service Virus Reference Laboratory, Colindale) for antibodies to HLTV-III. Statistical analysis of the data was performed using the Mann-Whitney and $\chi^{2}$ tests where indicated. ${ }^{3}$

\section{Results}

Six inpatients (four with haemophilia $A$, one with haemophilia $B$, and one with von Willebrand's disease) had changes of pulmonary tuberculosis in chest radiographs associated with strongly positive reactions on Mantoux skin testing. One other inpatient with haemophilia $A$ and an outpatient with haemophilia B showed positive skin reactions only. None of the patients, unlike some of the children with leukaemia, developed miliary tuberculosis.

The Table gives details of treatment, total white cell counts, lymphocyte counts, platelet counts, T4:T8 ratios, and numbers of patients with hypergammaglobulinaemia (compared with reference values related to age).

Patients who acquired pulmonary tuberculosis or were reactors had received significantly more factor replacement treatment than either the inpatient or the outpatient group who did not develop the disease, whether treatment was considered as the mean annual replacement over four years $(p<0.05)$ or replacement during the year before exposure to the disease $(p<0.05)$. There were, however, no significant differences between the patient groups when age, total white cell counts, lymphocyte counts, platelet counts, and T4:T8 ratios were analysed. Hypergammaglobulinaemia was found in three of the eight children with pulmonary tuberculosis or positive skin reactions and in five of nine inpatients who did not develop tuberculosis. The presence of hypergammaglobulinaemia did not relate to treatment or any other measured variable.

\section{Discussion}

Outbreaks of Mycobacterium tuberculosis in the United Kingdom still occur. ${ }^{9-11}$ The unusual and surprising feature of this outbreak was an incidence of primary tuberculosis among children with bleeding disorders that was comparable with that in an immunocompromised group, suggesting a possible underlying defect in cell mediated immunity. We established that those children who developed tuberculosis had received significantly more replacement treatment than those who did not develop tuberculosis, whether measured on a mean yearly basis or in the year before tuberculosis developed. Type of replacement treatment did not seem to relate to subsequent development of tuberculosis as patients treated with factor VIII concentrates, factor IX concentrates, and cryoprecipitate developed primary tuberculosis.

We were unable to show any significant immunological differences between those who acquired tuberculosis and those who did not. Although we were unable to perform the immunological tests on the children at the time of exposure to the disease, their ability to mount a delayed hypersensitivity reaction to tuberculosis in the Mantoux test and the fact that none progressed to miliary tuberculosis suggests cell mediated. immunity was not significantly impaired at this time. Furthermore, there was no correlation between seropositivity for HTLV-III and development of primary tuberculosis. The two boys with HTLV-III antibodies, however, showed much later conversion of their Mantoux skin tests than the six other affected boys. Among the patients exposed to the 
index case there was a correlation between the duration of admission and development of tuberculosis. The haemophiliacs who developed tuberculosis had a mean duration of admission of 5.4 days (range one to 13 days), while those who did not develop tuberculosis had a mean duration of admission of 4.8 days (range two to 14 days). These differences were not significant. Outpatient attendances typically last for about one hour with patients waiting in the ward entrance. One outpatient with haemophilia B was found to be a positive skin reactor after one such attendance.

Proximity of the child to the index case child was a predisposing factor to developing tuberculosis. The mother of the index case, however, was known to have circulated in the ward, and this may have been an important (but unmeasurable) factor in determining subsequent development of primary tuberculosis in patients at the opposite end of the ward who were only briefly exposed.

We were unable to identify any immunological defect or correlation with known previous exposure to HTLV-III virus (evidence by seropositivity in only two patients) among those with bleeding disorders that would account for a rate of attack similar to that in the patients known to be immunocompromised. Our investigations may have been inadequate in detecting altered immunological states rather than there being no defect present.

We thank Dr P Mortimer for kindly testing the sera for antibodies to HTLV-III virus and Mrs P Mann for typing the manuscript.

MD Williams and $\mathrm{K} \mathrm{Al-Rubei}$ are in receipt of Armour research fellowships.

\section{References}

' Beddall AC, Hill FGH, George RH. Haemophilia and tuberculosis. Lancet 1983; i: 1226.

${ }^{2}$ Pneumocystis carinii pneumonia among persons with haemophilia A. MMWR 1982;31:365-7.

${ }^{3}$ Ragni MV, Lewis JH, Spero JA, Bontempo F. Acquired immunodeficiency-like syndrome in two haemophiliacs. Lancet 1983; i: 213-4.

4 Lechner K, Niessner H, Bettelheim E, et al. T-cell alterations in hemophiliacs treated with commercial clotting factor concentrates. Thromb Haemost 1983;50(2):552-6.

${ }^{5}$ Luban NLC, Kelleher JF. Altered distribution of T-lymphocyte subpopulations in children and adolescents with hemophilia. Lancet 1983; i: 503-5.

- Ledermann MM, Ratnoff OD, Scillian JJ, Jones PK, Schachter B. Impaired cell-mediated immunity in patients with classic hemophilia. N Engl J Med 1983;308:79-83.

${ }^{7}$ Menitove JE, Aster RH, Capser JT, et al. T-lymphocyte subpopulations in patients with classic hemophilia treated with cryoprecipitate and lyophilised concentrates. $N$ Engl J Med 1983;308:83-6.

${ }^{8}$ Lee CA, Janossy G, Ashley J, Kernoff PBA. Plasma fractionation methods and T-cell subsets in haemophilia. Lancet 1983;ii: 158-9.

'Smith WHR, Davies D, Mason KD, Onions JP. Intraoral and pulmonary tuberculosis following dental treatment. Lancet $1982 ; \mathrm{i}: 842-4$

${ }^{10}$ Spencer-Jones J. A tuberculous outbreak in Deal, Kent. Lancet 1982;i:1060-1.

"Hill JD, Stevenson JK. Tuberculosis in unvaccinated children, adolescents, and young adults: a city epidemic. $\mathrm{Br} \mathrm{Med} J$ 1983; 286: 1471-3. 